\title{
Vocational Pathways in the Early Part of a Career: An Australian Study
}

\author{
James A. Athanasou
}

\begin{abstract}
The vocational pathways of a representative national sample of Australian school students $(N=1,201)$ were examined over a 7 -year period after the students left school. Results indicated that there was a disparity between the students' initial vocational interests and their occupations at the beginning of their careers. Only $21 \%$ of the students were in identical high-point interest areas at initial assessment and 7 years later. The results suggested that there was a period of career exploration that was followed by adjustment to the labor market.
\end{abstract}

The purpose of this study was to explore the occupational pathways of a nationally representative cohort of school students, particularly their vocational interests. The study focused on the variation in career paths that occurs in the early years after school in Australia. This variation is a familiar phenomenon for career practitioners, researchers, or laypersons and is an aspect of job mobility that might reflect career development in a modern working life (Rosenfeld, 1992). For instance, analysis of labor market experiences in the United Kingdom from 1915 to 1990 indicated that British men and women held an average of 5 jobs (Booth, Francesconi, \& GarciaSerrano, 1999) compared with 4 jobs for German men over their lifetime and approximately 10 for men in the United States. A significant component of this overall mobility, however, was the instability in the first 10 years, which has been described as "job shopping" (Stigler, 1962).

In Britain, approximately half of all the lifetime job changes occurred in the first 10 years, and this proportion was similar for men in Germany, whereas for men in the United States, an estimated two thirds of all jobs occurred in that time (Booth et al., 1999, p. 43; Hall, 1982; Winkelmann, 1994). More recent data from the Youth Cohort of the U.S. National Longitudinal Surveys, conducted by the Bureau of Labor Statistics (1993), indicated that the typical individual had seven to eight jobs between ages 18 and 30. Official labor force statistics in Australia also confirmed that the proportion of persons who were job mobile (i.e., changed employers, business, or location) was greater in the younger age groups. For 15-19year-old individuals, the proportion who were job mobile was approximately $20.1 \%$, increasing to a maximum of $27.3 \%$ for ages 20 to 24 and declining gradually thereafter to $6.9 \%$ for individuals who were 55 years old and over (Table 4, Australian Bureau of Statistics, 2001, p. 15).

James A. Athanasou, Faculty of Education, University of Tecbnology. The author thanks the Australian Council for Edwcational Research ( $A C E R$ ) for providing the Youth in Transition data and for allowing him to work at ACER. The cooperation and assistance of Terence Tracey, Arizona State University, in providing and modifying the program for the randomization test is also gratefully acknowledged. Correspondence concerning this article should be addressed to James A. Athanasou, Faculty of Education, University of Technology, PO Box 123, Broadway 2007, Sydney, Australia (e-mail: Jim.Athanasou@uts.edu.au). 
In analyzing career pathways, job mobility might be identified readily with instability, but it may also be characterized as a search for the most compatible environment in one's life. When viewed as a search for compatibility, mobility acts as a proactive force in one's career path (see Topel \& Ward, 1992). Although positive elements of employment mobility have been considered by some researchers, the levels of instability have captured most of the attention. In an Australian context, Dwyer and Wyn (1998) described education and vocational patterns as nonlinear. Dwyer, Harwood, and Tyler's (1998) study followed young people 7 years after they left school. They focused mainly on individuals who were still involved with further education $(N=1,309)$ and described the largest group as adjusting to the reality of their status in meaningful and complex ways.

On the other hand, Holland $(1997$, p. 64$)$ recently pointed out the inherent stability of occupational pathways. He described the snowball effects of a career and listed the many barriers that exist regarding change. In emphasizing stability, Holland (1997) took a longer term view of career pathways and noted that

\begin{abstract}
the average career is both focused and stabilized by relatively constant dispositions, special talents, expectations, irreversible choices, eredentials, and other baggage that workers acquire, and by the benign and biased environments that everyone encounters at every age . . . stability is the normbecause workers soon become active seckers of a limited range of congruent jobs and because employers discourage change through common hiring practices and biases of age, appearance, sex, training and work history. Family friends, coworkers, and relatives also press for stability because they usually have a stake in a worker's income, friendship, and power. (pp. 12-13)
\end{abstract}

The stability proposed by Holland (1997) is evident in his concept of the congruence of vocational interests and occupational choices. Furthermore, congruence is related to the long-term predictive validity of vocational interests. This has been studied in various age groups from the time of the pioneering work of Strong (1935) in his 5-year follow-up of the senior class of Stanford University. Recently, Fouad (1999) indicated that "somewhere between $40 \%$ and $60 \%$ of individuals are in occupations that may be predicted from their inventory results" (p. 202).

In an early study, McLaughlin and Tiedeman (1974) followed Year 12 students after 1,5 , and 11 years. They reported that the category of aspirations predicted approximately $58 \%$ after 1 year and $39 \%$ after 11 years, L. S. Gottfredson (1979) showed that approximately $70 \%$ to $80 \%$ of year-to-year aspirations of men aged 16-28 years were within the same Holland category. Studies of census data also showed that for both men and women, there is an increase in career stability over time and that many job changes involve transitions within the same major Holland type (see G. D. Gottfredson, 1977; L. S. Gottfredson \& Becker, 1981). Finally, in a study of Australian workers, the Holland category of a worker's first occupation was reported to be an effective indicator of the category of occupation 5 and 10 years later (Melamed \& Meir, 1981).

There have been relatively few studies of the predictive validity or occupational stability of interests, and those that exist have been limited to select groups, such as university students, and have been based on nonrandom samples. Moreover, they did not always focus on the initial vocational pathways in a career. Thus, there seems to be some scope for investigating the stability of pathways within vocational interest types to 
determine whether it applies to youth. Stability in the context of this study refers to the extent to which occupations in the early part of a career were congruent with vocational interests that were identified during high school.

The framework for this study was the Holland (1997) typology of vocational choices and occupations. This allowed for the classification of people and occupations in similar ways and permitted an assessment of consistency in career pathways. Furthermore, it did not penalize people for moving between jobs at the beginning of their working life, especially when they remained within a consistent career path. I used a national probability sample of Australian high school students to determine the link between interests and subsequent occupation in the early part of a career. Some details of the sample are described in the following paragraph and in the Method section of this article.

\section{Youth in Transition}

The Youth in Transition (Australian Council for Educational Research, n.d.-a) survey consists of a cohort of approximately 5,473 young people who were born in 1970. It is a part of the national Longitudinal Surveys of Australian Youth conducted by the Australian Council for Educational Research on behalf of the federal government. The objective of the surveys was to determine the main factors that affect employment, education, and training outcomes. The schools included government, independent, and Catholic school systems in every state and territory. These data have only been recently made available for analysis, and Lamb, Polesel, and Teese (1995) went so far as to say "it represents one of the most substantial long-term studies of outcomes undertaken in Australia" (p. 27).

I used this historical database to address two key research questions regarding the stability of career development and the predictive value of interests. Specifically, (a) What are the vocational pathways of Australian school students in the first few years after leaving school? and (b) To what extent is one's vocational interest reflected in the subsequent types of job(s) undertaken in the early part of a career?

\section{Method}

\section{Participants}

The participants in this study were involved in a two-stage stratified probability sample of students who were randomly selected from a nationwide sample of schools ( 25 students from each school). This comprised students (boys $=1,436$; girls $=1,273$ ) from the Youth in Transition (Australian Council for Educational Research, n.d.-b) study cohort. These students were first tested as part of the Australian Studies of School Performance in 1980. When contacted again in 1985, the mean age of the sample was 15.5 years $(S D=0.3)$. Participants were followed up by mail annually, and my study included only participants who were working full-time. The number of participants varied from a minimum of 846 , in 1985 , to a maximum of 1,236 , in $1988(1985, N=846 ; 1986, N=1,077 ; 1987, N=$ $1,042 ; 1988, N=1,236 ; 1989, N=1,163 ; 1990, N=1,082 ; 1991, N=1,201)$.

\section{Instrument}

The interest inventory that I used in this study was a 24 -item questionnaire that was based on Holland's (1997) typology of interests. The in- 
ventory was developed by the Australian Council for Educational Research (broadly, the Australian equivalent of the U. S. Educational Testing Service) for administration by mail in the Youth in Transition studies. It was 1 of the 12 sections of a larger survey. Students were asked "How do you feel about each of these activities?": bushwalking, working with machines and tools (Realistic [R]); doing all kinds of experiments (Investigative [I]); acting in plays (Artistic [A]); helping others (Social [S]); managing other people (Enterprising $[\mathrm{E}]$ ); and doing office work (Conventional $[\mathrm{C}]$ ). (See Australian Council for Educational Research, Longitudinal Surveys of Australian Youth, Technical Paper Number 5 for a complete copy of the survey questionnaire; a copy of the interest questionnaire is available from the author upon request.) Participants responded on a 4 -point scale from $1=$ like very much to $4=$ dislike very much. Due to restrictions of both space and response time, the questionnaire was limited to four items per scale and designed for moderate levels of internal consistency, with alpha coefficients for the six RIASEC scales of $0.80,0.60,0.63,0.54,0.64$, and 0.70 , respectively. The questionnaire has been used subsequently in other largescale studies and validated against subject choice (Ainley, Robinson, HarveyBeavis, Elsworth, \& Fleming, 1994; Athanasou, 2001).

\section{Procedure}

Participants were first contacted in schools and further data were collected over a 10-year period through an annual mail survey. The 1970 cohort (Australian Council for Educational Research, n.d.-b) was used in my study and was first assessed in 1980 and then followed up at yearly intervals from 1985 to 1994. A follow-up mail survey was used to obtain the occupation of those who were working. Respondents were classified on the basis of their Holland (1997) high point code (RIASEC). Scale scores were based on a Rasch item analysis that avoided problems of tied scores (see Athanasou, 2001, for further details). Cross-tabulations were computed between the person's Holland high-point code and the RIASEC code for the person's job over a 7-year period, using the Australian version of the Occupations Finder for the Self-Directed Search. This was only undertaken for participants who were working at the time of the follow-up survey. Cross-tabulations were adjusted for base rates of responding by the expected values for each cell, as in a chi-square analysis.

\section{Analysis}

A randomization test (Tracey, 1997) was then used to test the hypothesized ordering of relationship in the RIASEC hexagonal model. This test compared the predicted hexagonal relationship between caregories such as RI (i.c., Realistic Investigative) with RA, RS, RE, RC, IA, IS, IE, IC, AS, AE, AC, SE, SC, and EC. A correspondence index ranging from -1 through 0 to +1 indicated the extent of agreement. Further details of the analysis are contained in the Results section.

\section{Results}

\section{Vocational Pathways of Students in the First Few Years After Leaving School}

Table 1 shows the distribution of participants in the original sample and in the subsequent years. The students were classified by their high-point 


\section{TABLE 1}

\section{Percentage Distribution of the Holland High-Point Codes of Participants and Their Occupations Surveyed 1985-1991}

\begin{tabular}{|c|c|c|c|c|c|c|c|c|c|}
\hline $\begin{array}{l}\text { Holland } \\
\text { Type }\end{array}$ & Original & 1985 & 1986 & 1987 & 1988 & 1989 & 1990 & 1991 & $\begin{array}{l}\text { Employed } \\
\text { Persons in } \\
\text { Australia: }\end{array}$ \\
\hline Realistic & 25 & 38 & 33 & 38 & 35 & 36 & 34 & 31 & 4 \\
\hline ve & 12 & $\mathrm{c}$ & & & & & : & & 5 \\
\hline Artis & 6 & 1 & 1 & 1 & 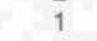 & & & & 3 \\
\hline Soc & 41 & 1 & . & 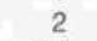 & 4 & 5 & 7 & 10 & 8 \\
\hline Ent & 11 & 43 & 42 & 32 & 25 & 23 & 2 & 1 & 16 \\
\hline Cor & 4 & 17 & 23 & 27 & 30 & 32 & 35 & 34 & 24 \\
\hline otal & 3,275 & 846 & 1,077 & 1,042 & 1,236 & 1,163 & 1,082 & 1,201 & $8,319,700$ \\
\hline
\end{tabular}

Note. Entries are expressed in percentages and are rounded. Columns contain different samples, and not all participants were working from 1985-1991.

"Australia Bureau of Statistics, Labor Statistics Australia, Catalogue No. 6101.0, August 1996, p. 74.

code on the interest questionnaire and in subsequent years by the Holland high-point code for their occupation. The final column of Table 1 indicates the estimated proportion of employees that were classified by the Holland code in the Australian labor force.

The R category increased its share of vocational pathways throughout the period, from $25 \%$ to $31 \%$ of respondents; this might reflect the large range of unskilled, semiskilled, and skilled occupations that involve outdoor, manual, technical, and practical work activities in the Australian labor market. The large, initial drop in the percentage of I (i.e,, scientific, medical) interests from $12 \%$ to $0 \%$ may reflect the long lead time required for entry into many of these professional and paraprofessional occupations. Even then, it is clear that many individuals with I interests either had not finished their training by 1991 or were not able to locate work in this field. A similar pattern was found for A interests, with $6 \%$ of persons indicating this as their highest interest at initial assessment, but only $2 \%$ remaining in employment in this field in 1991 . The largest absolute as well as relative change in interests was seen in the $\mathrm{S}$ category (i.e., social service, welfare, people contact occupations), which declined from a high of $41 \%$ at initial assessment to $10 \%$ in 1991 . Significant increases were observed for the E interests (i.e., business, entrepreneurial, and persuasive activities) from $11 \%$ to $18 \%$, but the most substantial increase was found for $\mathrm{C}$ interests (i.e., clerical, office, and computational work activities), which increased from $4 \%$ to $34 \%$. This reflected, in part, the significant proportion of clerical and office work activities in Australian employment.

\section{Vocational Interest and the Subsequent Type of Job(s) Undertaken}

The congruence between the initial high-point interest codes and those at follow-up in 1991 were available for 1,201 persons. Only $21 \%(256)$ were in identical high-point codes at the initial assessment and in 1991. These are shown in Table 2 (127 out of 369 in the R category, 6 out of 64 for I, 5 out of 21 for A, 65 out of 120 for S, 23 out of 218 for E, and 30 out of 409 for $\mathrm{C}$ types). Congruence rates for subsequent years remained 
TABLE 2

Congruence of the Holland High-Point Codes of Participants in 1985 and in 1991

\begin{tabular}{lrrrrrr}
\hline & \multicolumn{7}{c}{1991} \\
\cline { 2 - 7 } 1985 & R & I & A & S & E & C \\
\hline Realistic (R) & 127 & 12 & 3 & 21 & 39 & 72 \\
Investigative (I) & 81 & 6 & 1 & 10 & 24 & 39 \\
Artistic (A) & 10 & 9 & 5 & 10 & 17 & 22 \\
Social (S) & 97 & 31 & 10 & 65 & 106 & 208 \\
Enterprising (E) & 44 & 4 & 2 & 8 & 23 & 38 \\
Conventional (C) & 10 & 2 & 0 & 6 & 9 & 30 \\
\hline
\end{tabular}

fairly constant $(1985,21 \% ; 1986,18 \% ; 1987,19 \% ; 1988,19 \% ; 1989,21 \%$; $1990,21 \% ; 1991,21 \%)$. However, this type of comparison does not take into account the predicted movement to adjacent, alternate, and opposite types around the Holland (1997) hexagonal arrangement in which individuals may move to the next most congruent type. This was tested in the correspondence analysis for all possible comparisons from 1985 to 1991.

Table 3 shows the correspondence across time between the high-point codes for interests and occupations in subsequent years, according to the hexagonal arrangement of interests. There was no clear pattern in a participant's vocational type and his or her subsequent career pathways. The results indicated considerable instability in the hexagonal ordering of interest types. Only two out of the seven correspondence indices were significant $(p<.05)$.

\section{Discussion and Conclusion}

The findings from this study indicated that the vocational interests of high school students in Australia were only partly congruent with their initial career pathways. Approximately $21 \%$ remained in identical vocational categories at initial assessment and 7 years later; this was significantly less than expected (cf. Fouad, 1999, p. 201). Furthermore, movement into other categories of work did not correspond to the predicted order in the Holland (1997) hexagonal typology.

TABLE 3

Correspondence Indices for Original Holland Interest Codes and Occupations in Subsequent Years

\begin{tabular}{lcccc}
\hline \hline Year & $\begin{array}{c}\text { Predictions } \\
\text { Met }\end{array}$ & $\begin{array}{c}\text { Predictions } \\
\text { Tied }\end{array}$ & $\begin{array}{c}\text { Correspondence } \\
\text { Index }\end{array}$ & Probability \\
\hline 1985 & 163 & 18 & .2242 & .5125 \\
1986 & 167 & 5 & .2064 & .3708 \\
1987 & 202 & 3 & .4484 & .0250 \\
1988 & 195 & 4 & .4021 & .0486 \\
1989 & 197 & 4 & .4164 & .0917 \\
1990 & 166 & 2 & .1886 & .5667 \\
1991 & 201 & 4 & .4448 & .0556 \\
\hline
\end{tabular}


It is possible that although the pathways people chose did not conform to the predicted hexagonal ordering of interests in the Holland (1997) typology, they tended to reflect the structure of opportunities in the Australian labor market. Individuals who have high I, A, or S interests seem unlikely to find sufficient employment opportunities, whereas despite the lack of interest among students for conventional careers, there was an oversupply of opportunities in this area.

This mismatch might account for some but not all aspects of the instability that characterized the early years in the labor force. Nevertheless, the career pathways were not entirely random, and they certainly displayed some order and a degree of congruence. However, it is difficult to account for the varied directions of "job shopping."

A major challenge for career practitioners is to find ways to maximize the value of interest questionnaires so that we can help to increase the proportion of people entering work that interests them. Many students were at a particular interest disadvantage in the labor market. This raises the issue of why interest assessment should be undertaken and how the results might best be used. A negative aspect of these findings for practitioners is the question raised about the stability (or predictive validity) of interests in the early part of a career. Indeed, vocational interests may have to be sacrificed in order to accommodate other factors, such as educational achievements, natural abilities, personal or social issues, and available opportunities.

An advantage of this study is that it used a coherent and consistent theoretical classification for both persons and jobs. This facilitated meaningful comparisons across time. Moreover, the advantage of using a broad vocational typology is that it allowed individuals to change jobs or industry but to still remain within the same Holland (1997) cluster. The use of correspondence analysis went further than assessing the congruence of high-point codes to test the consistency of mobility or transfer within the hexagonal arrangement of interests.

A further advantage of this study was the large national probability sample; a limitation was the high dropout rate of participants. This is characteristic of many follow-up studies that rely on participants to mail their responses; this concern has now been addressed by using telephone follow-ups. Second, the study was also dependent on the validity of the results from a brief assessment of vocational interests that had only moderate reliability. Different results might have been obtained using longer scales to assess vocational interests. Third, there was no way control for factors other than interest that might also affect mobility, such as opportunities or educational achievement. Further studies may also need to consider other constructs within the Holland (1997) theory, such as combinations of consistency, differentiation, identity, and education level. Fourth, the study was undertaken during a period of economic recession with high youth unemployment, and this fact might have influenced vocational pathways. Finally, the historical nature of the data may limit any generalization to future labor markets.

This study showed that approximately one fifth of high school pupils demonstrated some congruence in interests and occupations in the early stages of their career and demonstrated that there was considerable variation in the initial career pathways. In one sense, it is remarkable that there is any stability in careers, given the myriad of potential influences likely to destabilize any life. Given that the cost (personal, social, economic) of occupational change 
is great and increases over time, then one of the few periods when it is most feasible for an individual to experiment is at the earliest period of career development. Career mobility or instability may be a positive attempt to find a more conducive working environment. A disturbing aspect of these results for career practitioners, however, is that the modern workplace may not allow high school pupils to fulfil their vocational interests and may encourage instability in their career pathways.

\section{References}

Ainley, J., Robinson, L., Harvey-Beavis, A., Elsworth, G., \& Fleming, M. (1994). Subject choice in years 11 and 12 . Canberra: Australian Government Publishing Service.

Athanasou, J. A. (2001) Analysis of responses to vocational interest items: A study of Australian high school students. Journal of Career Assessment, 9, 61-79.

Australian Bureau of Statistics. (2001). Job mobility. Catalogue No. 6209.0. Canberra, Australian Capital Territory: Author.

Australian Council for Educational Rescarch. (n.d.a). Overview of the longitudinal surveys of Australian youth program. Techical Paper Number 2. Melbourne: Australian Council for Educational Research.

Australian Council for Educational Research. (n.d.-b). The Youth in Transition 1970 cohort questionnaires: 1980, 1985-1994. Tecbnical Paper Number 5. Melbourne: Australian Council for Educational Research.

Booth, A. L., Francesconi, M, \& Garcia-Serrano, C. (1999). Job tenure and job mobility in Britain. Industrial and Labor Relations Review, 53, 43-70.

Bureau of Labor Statistics. (1993): Work and family: Turning thirty job mobility and labor market attachment. Data from the national longitudinal surveys. Report 862 ED366815. Washington, DC: U. S. Department of Labor.

Dwyer, P., Harwood, A., \& Tyler, D. (1998). Life-patterns, choices, careers: 19911998. Research Report 17. Parkville, Victoria: University of Melbourne.

Dwyer, P., \& Wyn, J. (1998). Post-compulsory education policy in Australia and its impact on participant pathways and outcomes in the 1990s, Journal of Education Policy, 13, 285-300.

Fouad, N. A. (1999). Validity evidence for interest inventories, In M. L. Savickas \& A. R. Spokane (Eds.), Vocational interests. Meaning, mensurement and counseling use. (pp. 193-209). Palo Alto, CA: Davies-Black.

Gottfredson, G, D. (1977). Career stability and redirection in adulthood. Journal of Applicd Psychalogy, 62, 436-445.

Gottfredson, L. S. (1979). Aspiration-job match: Age trends in a large nationally representative sample of young White men. Joumal of Counseling Psychology, 26, 319-328.

Gottfredson, L. S., \& Becker, H. J. (1981). A challenge to vocational psychology: How important are aspirations in determining male career development? Journal of Vocational Belsavior, 19, 251-289.

Hall, R. E. (1982). The importance of lifetime jobs in the United States economy. American Economic Review, 72, 716-24.

Holland, J. L. (1997). Making vocational choices: A theory of pocational personalities and work environments. (3rd ed.). Odessa, FL: Psychological Assessment Resources.

Lamb, S., Polesel, J., \& Teese, R. (1995). 'Where do they go?' An evaluation of sources of data used for the monitoring of students' destinations and other cducational outcomes in Australia (National Board of Employment, Education and Training, Commissioned Report No. 40). Canberra: Australian Government Publishing Service.

McLaughlin, D. H., \& Tiedeman, D. V. (1974). Eleven-year career stability and change as reflected in Project Talent data through the Flanagan, Holland and Roe occupational classification systems. Journal of Vocational Behavior, 5, 177-196. 
Melamed, S., \& Meir, E. I. (1981). The relationship between interests-job incongruity and selection of avocational activity. Journal of Vocational Behavior, 14, 310-325.

Rosenfeld, R. A. (1992). Job mobility and career processes. Annual Revicw of Sociology, 18, 39-61.

Stigler, G. J. (1962). Information in the labor market. Journal of Political Economy, $70,94-105$.

Strong, E. K., Jr. (1935). Predictive value of the Vocational Interest Test. Journal of Educational Psychology, 26, 332.

Topel, R. H., \& Ward, M. P. (1992). Job mobility and the careers of young men. The Quarterly Journal of Economics, 107, 439-479.

Tracey, T. J. G. (1997). RANDALL: A Microsoft FORTRAN program for a randomization test of hypothesised order relations. Educational and Psydotogical Measurement, 57, 164-168,

Winkelmann, R. (1994). Count data models, economic theory and an application to labor mobility. In Lecture notes in economics and mathematical systems (p. 410 ). Berlin: Springer-Verlag. 